\title{
Awareness of congenital cytomegalovirus infection among young people studying non-medical subjects
}

\author{
Świadomość zdrowotna na temat zakażenia wrodzonego CMV wśród \\ studentów kierunków niemedycznych
}

\author{
Agnieszka Trzcińska' ${ }^{1, A-D, F \oplus}$, Agnieszka Częścik ${ }^{1, A-B, E \oplus}$, Joanna Siennicka ${ }^{1, A, E \oplus ~}$ \\ ${ }^{\prime}$ Department of Virology, National Institute of Public Health - National Institute of Hygiene, Warsaw, Poland \\ A - Research concept and design, B - Collection and/or assembly of data, C - Data analysis and interpretation, \\ $D$ - Writing the article, $E$ - Critical revision of the article, $F$ - Final approval of article
}

Trzcińska A, Częścik A, Siennicka J. Awareness of congenital cytomegalovirus infection among young people studying non-medical subjects. Med Og Nauk Zdr. 2019; 25(4): 240-244. DOI: 10.26444/monz/114383

\begin{abstract}
Introduction. Congenital infections are still a serious public health problem. They may be related, among others, to the lack of immunization against many pathogens that would reduce the number of cases of infection among pregnant women. In this situation, educational activities are important, disseminating knowledge about available prophylaxis.

Objective. Aim of the study is to assess the state of knowledge of young people studying in fields not related to medical care, about congenital infections, mainly congenital CMV infection. Materials and method. The study was conducted by a questionnaire survey. The study group consisted of 225 students aged 20-29 (99 women and 126 men). The questions concerned, among others: knowledge of diseasees/infections affecting the foetus/child; sources and activities related to the risk of CMV infection; hygiene behaviours that can help prevent CMV infection.

Results. Down syndrome (88\%) and autism (80.9\%) belonged to the most frequently reported diseases that may affect children. Knowledge of congenital infections, in addition to congenital toxoplasmosis (28.9\%), was below $10 \%$. Knowledge of the fact that CMV infection can be transmitted from mother to foetus was confirmed by $16 / 225$ respondents. Only $8.9 \%$ of the respondents knew at least one hygienic behaviour that could contribute to a reduction in the number of CMV infections, and over $91 \%$ did not indicate any such behaviour. Conclusion. The survey conducted among students revealed that knowledge about congenital infections possessed by potential parents is not satisfactory. The study clearly indicated the need to undertake educational activities.
\end{abstract}

\section{Key words}

congenital infections, CMV, awareness, students

\begin{abstract}
Streszczenie
Wprowadzenie. Zakażenia wrodzone nadal stanowią poważny problem zdrowia publicznego. Może to być związane m.in. z faktem, iż w przypadku wielu patogenów brakuje możliwości immunizacji, która pozwoliłaby na ograniczenie liczby przypadków zakażeń wśród kobiet ciężarnych. W takiej sytuacji duże znaczenie mają działania edukacyjne, szerzące wiedzę na temat dostępnej profilaktyki.

Cel pracy. Ocena wiedzy młodzieży studiującej na kierunkach niezwiązanych z opieką medyczną na temat zakażeń wrodzonych, głównie zakażenia wrodzonego CMV.

Materiały i metody. Badanie miało charakter badania ankietowego. Grupę badaną stanowiło 225 studentów w wieku od 20 do 29 lat (99 kobiet oraz 126 mężczyzn). Pytania dotyczyły m.in.: znajomości jednostek chorobowych/ zakażeń i zarażeń dotykających płód/dziecko; źródeł zakażenia i czynności związanych z ryzykiem zakażenia CMV; zachowań higienicznych, które mogą pomagać w zapobieganiu zakażeniu CMV.

Wyniki.Donajczęściejwskazywanychjednostekchorobowych, które mogą dotykać płód/dziecko należały zespół Downa (88\%) i autyzm (80,9\%). Znajomość zakażeń wrodzonych, poza wrodzoną toksoplazmozą (28,9\%), kształtowała się na poziomie poniżej $10 \%$. Fakt, że zakażenie CMV może być przenoszone z matki do płodu był znany 16 spośród 225 ankietowanych. Tylko 8,9\% ankietowanych znało przynajmniej jedno zachowanie higieniczne, które może przyczyniać się do ograniczenia liczby zakażeń CMV, a ponad $91 \%$ nie wskazało żadnego takiego prawidłowego zachowania.

Posumowanie. Przeprowadzone wśród studentów kierunków niemedycznych badanie ankietowe ujawniło, że posiadana przez potencjalnych przyszłych rodziców wiedza na temat zakażeń wrodzonych nie jest zadowalająca. Badanie jednoznacznie wskazuje na konieczność podjęcia działań o charakterze edukacyjnym.
\end{abstract}

\section{Słowa kluczowe}

zakażenia wrodzone, CMV, świadomość zdrowotna, studenci

\footnotetext{
Address for correspondence: Agnieszka Trzcińska, Department of Virology, National Institute of Public Health - National Institute of Hygiene, Poland E-mail: atrzcinska@pzh.gov.pl

Received: 26.09.2019; Accepted:18.11.2019; first published: 02.12.2019
} 


\section{INTRODUCTION}

The scale of publicity of the problem with the Zika virus (ZIKV) epidemic in South America, and especially its serious effects for pregnant women and their children, drew the attention of the general public to the relationship between infections with other pathogens, and the occurrence of malformations in the foetus which are just as serious as in the case of the Zika virus [1]. For example, microcephaly, which is mainly associated with Zika virus infection during pregnancy, can also be the result of infection with three other original 'TORCH' pathogens: cytomegalovirus (CMV), rubella virus (RBV) and Toxoplasma gondii [2]. Depending on the pathogen, the type of infection (primary, reactivation, reinfection), and pregnancy trimester in which infection occurs, the vertical transmission of the infectious agent from the mother to the developing foetus can have different effects - from complete lack of consistency to serious malformations and, in extreme cases, to pregnancy loss due to spontaneous abortion, foetal death or premature birth [3].

Infections that may also have a direct impact on the child's development may occur both in the prenatal period (congenital infections) and during delivery (perinatal infections). The main infectious agents that cause congenital infections are pathogens from the TORCH group (Toxoplasma gondii; others: Listeria monocytogenes, Treponema pallidium, parvovirus, HIV, Varicella-zoster virus; rubella virus; cytomegalovirus and herpes simplex virus type 1 and 2), and the Zika virus which has been studied intensively in recent years [4]. The cytomegalovirus is an indisputable leader among these pathogens. CMV congenital infection affects, an average, $0.7 \%$ of live births worldwide and is the leading cause of congenital neurological handicap of infectious origin [5], and the main, non-genetic cause of hearing loss in children $[6,7]$.

Cytomegalovirus is the most common infectious cause of birth defects in the United States. One in 200 babies is born with congenital CMV. One in five babies with congenital CMV will have symptoms or long-term health problems, such as hearing loss [8]. Every day in the UK, two or three newborn babies will be affected by cytomegalovirus (CMV), equivalent to almost 1,000 babies every year. Congenital CMV costs the UK $£ 750 m$ a year [9]. Congenital infections associated with various infectious agents are still a serious public health problem, despite detailed knowledge about them. This is related, among others, to the fact that despite intensive research, for many pathogens, effective immunization strategies that would reduce the incidence of infections among pregnant women, are still not available. Therefore, in order to reduce the risk of infection of pregnant women, great emphasis is placed on education which should inform about the effects of such infections, and spread knowledge about available preventive measures, such as appropriate hygiene measures.

\section{OBJECTIVE}

The aim of the study was to assess awareness about congenital infections, mainly congenital CMV infection, among young people studying non-medical subjects, based on a questionnaire survey.

\section{MATERIALS AND METHOD}

The research tool used was an anonymous questionnaire prepared by the authors of the study based on current data in the literature. Participation in the study was voluntary. The respondents were not able to use the help of scientific sources when completing the questionnaire. The survey presented to students in one of non-medical universities in Warsaw, consisted of two parts. In the first part, questions were provided to characterize the study group. The questions concerned, among others, gender, age, having children, possible work in healthcare facilities, such as a hospital, clinic or medical laboratory. In the second part of the survey, detailed questions were provided, concerning:

- knowledge of disease /infections affecting the fetus / child; - knowledge of the term 'congenital cytomegalovirus (CMV) infection' and the fact that CMV infection can be transmitted from the mother to the foetus;

- sources of infection and activities related to the risk of CMV infection;

- hygiene preventive measures that may be helpful in the prevention of congenital infections, including congenital cytomegalovirus.

Data obtained on the basis of the questionnaire were statistically analysed using the $\chi^{2}$ test. The level of significance assumed in the analysis was $\mathrm{p}=0.05$.

\section{RESULTS}

The survey covered 225 students aged 20-29 years, 99 women (44\%) aged 20-28 (mean: 22.7 years, median: 23 years), and 126 men (56\%) aged 20-29 (average: 22.6 years, median: 22 years). Only two people had a child (0.9\%), and frequent contact with children under five years of age was declared by $34.7 \%$ of respondents (78/225) - 43 women (43.4\%) and 35 men $(27.8 \%)$. Four people (1.8\%) answered 'yes' to a question about work in the past or present in a healthcare facility.

The most often indicated diseases/infections by the students that may affect the foetus/child were Down's syndrome (88\%), autism (80.9\%), and alcohol foetal syndrome (67.1\%). Knowledge of congenital infections, except congenital toxoplasmosis (28.9\%), was below 10\% (Fig. 1). The largest group of $78 / 225$ people $(34.7 \%)$ were the respondents who indicated four out of nine given disease units/infections,

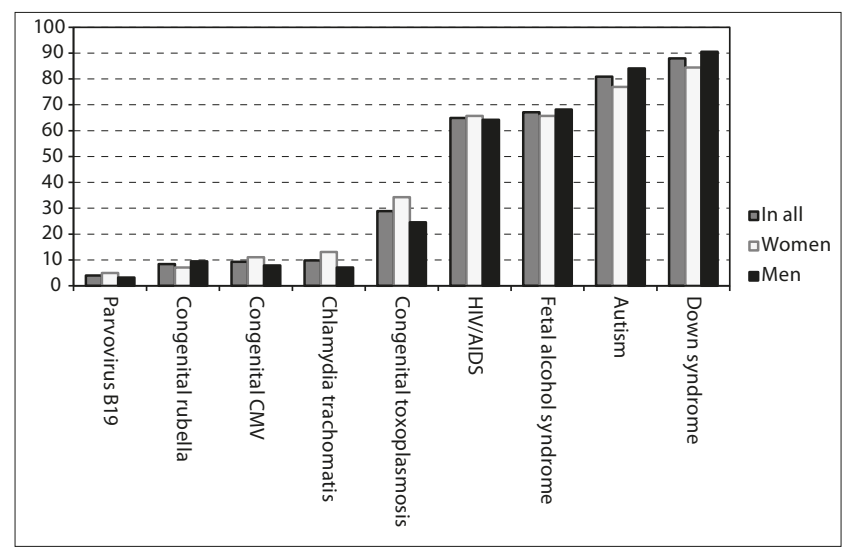

Figure 1. Knowledge (\%) among students about diseases / infections affecting the fetus /child 
slightly fewer people (20.4\%) indicated three units, and $14.2 \%$ knew five of the mentioned disease units. Eleven people (4.9\%) did not mark any, and three (1.3\%) knew as many as eight out of nine mentioned disease units/infections. The full list of diseases was not indicated by any of the respondents. Observed differences, in the knowledge of particular disease units, between men and women were not statistically significant $(\mathrm{p}<0.05)$. Statistically significant differences were observed in the declared knowledge of particular disease units/infections (e.g. parvovirus B19 versus Down's syndrome, parvovirus B19 versus autism, congenital CMV versus Down's syndrome, congenital CMV versus HIV/AIDS, congenital CMV versus alcoholic foetal syndrome, congenital CMV versus congenital toxoplasmosis).

Awareness of the fact that cytomegalovirus infection can be transmitted from mother to foetus was confirmed by $16 / 225$ respondents $(7.1 \%)$ - 9/99 (9.1\%) women and 7/126 $(5.6 \%)$ men (statistically non-significant difference; $\chi^{2}=1.049$; $\mathrm{p}=0.306)$. Among these 16 people, none had children, nine had frequent contact with children below five years of age, two worked (in the past or present) in a medical facility. $20 / 225$ (8.9\%) people, in this $12 / 99$ (12.1\%) women and 8/126 $(6.3 \%)$ men (statistically non-significant difference; $\chi^{2}=2.281$; $\mathrm{p}=0.131$ ), had heard that CMV infection can be dangerous to the foetus. Among these people, none had children, but 12 had frequent contact with children under five. Of the 225 surveyed students, only 24 (10.7\%) had ever heard the term 'congenital cytomegalovirus infection'(cCMV) - 12 women and 12 men. The source of information was indicated as TV/radio (10 people), press (4 people), friends (6 people), school (4 people), others (6 people). None of them indicated a doctor as the source of information, and more than one source was marked by six people. 'Yes' to all three questions regarding the transmission of maternal CMV infection to the foetus, the risk of this infection for the foetus, and knowledge of the term 'congenital CMV infection' were answered by $12 / 225$ people $(5.3 \%)$ - 8/99 women (8.1\%) and 4/126 men (3.2\%) (Tab. 1). As many as $199 / 225$ people $(88.4 \%)$ could not identify any clinical material that could be a potential source of cytomegalovirus infection, while others most often indicated blood and breast milk.

A similar number of people $(197 / 225 ; 87.6 \%)$ answered negatively the question regarding knowledge of activities that may be associated with the risk of CMV infection. The others most frequently indicated blood transfusions (9.8\%) and breastfeeding (6.2\%). Knowledge of more than one activity

Table 1. Awareness about the problem of congenital cytomegalovirus infection

\begin{tabular}{lcccc}
\hline Question & Answer & $\begin{array}{c}\text { In all } \\
\mathrm{N}(\%)\end{array}$ & $\begin{array}{c}\text { Women } \\
\mathrm{N}(\%)\end{array}$ & $\begin{array}{c}\text { Men } \\
\mathrm{N}(\%)\end{array}$ \\
\hline $\begin{array}{l}\text { Have you ever heard that } \\
\text { cytomegalovirus (CMV) } \\
\text { infection can be transmitted } \\
\text { from mother to fetus? }\end{array}$ & Yes & $16(7.1 \%)$ & $9(9.1 \%)$ & $7(5.6 \%)$ \\
\cline { 2 - 5 } & No & $209(92.9 \%)$ & $90(90.9 \%)$ & $119(94.4 \%)$ \\
\hline $\begin{array}{l}\text { Have you ever heard that } \\
\text { cytomegalovirus (CMV) } \\
\text { infection can be dangerous to } \\
\text { the fetus? }\end{array}$ & Yes & $20(8.9 \%)$ & $12(12.1 \%)$ & $8(6.3 \%)$ \\
\cline { 2 - 5 } & No & $205(91.1 \%)$ & $87(87.9 \%)$ & $118(93.7 \%)$ \\
\hline $\begin{array}{l}\text { Have you ever heard the term } \\
\text { "congenital cytomegalovirus } \\
\text { infection (cCMV)"? }\end{array}$ & Yes & $24(10.7 \%)$ & $12(12.1 \%)$ & $12(9.5 \%)$ \\
\cline { 2 - 5 } & No & $201(89.3 \%)$ & $87(87.9 \%)$ & $114(90.5 \%)$ \\
\hline
\end{tabular}

$\mathrm{N}$ - number of students related to the risk of CMV infection was declared by 17 people (Tab. 2). Awareness that simple hygienic activities can reduce the risk of viral infections was very low. Over $91 \%$ of the students did not indicate any correct hygienic measure (Tab.3). Ten women and ten men $(20 / 225 ; 8.9 \%)$ knew at least one hygienic measure that could contribute to reducing the number of CMV infections. The most frequently mentioned correct hygienic measure was to follow hygienic procedures in the workplace, such as a hospital, clinic or laboratory.

Table 2. Knowledge about CMV infection

From these clinical materials, please indicate those you have heard that may be a possible source of cytomegalovirus (CMV) infection.

\begin{tabular}{lccc}
\hline Answer & In all & Women & Men \\
\hline Urine & $\mathrm{N}(\%)$ & $\mathrm{N}(\%)$ & $\mathrm{N}(\%)$ \\
\hline Breast milk & $5(2.2)$ & $4(4.0)$ & $1(0.8)$ \\
\hline Tears & $14(6.2)$ & $6(6.1)$ & $8(6.4)$ \\
\hline Saliva & $0(0)$ & $0(0)$ & $0(0)$ \\
\hline Vaginal secretions & $9(4.0)$ & $5(5.1)$ & $4(3.2)$ \\
\hline Blood & $7(3.1)$ & $3(3.0)$ & $4(3.2)$ \\
\hline Sperm & $17(7.6)$ & $10(10.1)$ & $7(5.6)$ \\
\hline Feces & $7(3.1)$ & $2(2.0)$ & $5(4.0)$ \\
\hline Ido not know any & $5(2.2)$ & $3(3.0)$ & $2(1.6)$ \\
\hline Amon
\end{tabular}

Among the activities listed below, please indicate those you heard, that may be associated with the risk of cytomegalovirus (CMV).

\begin{tabular}{lccc}
\hline Answer & $\begin{array}{c}\text { In all } \\
\mathrm{N}(\%)\end{array}$ & $\begin{array}{c}\text { Women } \\
\mathrm{N}(\%)\end{array}$ & $\begin{array}{c}\text { Men } \\
\mathrm{N}(\%)\end{array}$ \\
\hline Organ transplantation & $5(2.2)$ & $1(1.0)$ & $4(3.2)$ \\
\hline Blood transfusion & $22(9.8)$ & $8(8.1)$ & $14(11.1)$ \\
\hline Kissing a child on or near the mouth & $6(2.7)$ & $4(4.0)$ & $2(1.6)$ \\
\hline Contact with dirty diapers & $7(3.1)$ & $3(3.0)$ & $4(3.2)$ \\
\hline Breastfeeding & $14(6.2)$ & $4(4.0)$ & $10(7.9)$ \\
\hline I do not know any & $197(87.6)$ & $87(87.9)$ & $110(87.3)$ \\
\hline
\end{tabular}

Table 3. Knowledge about prevention of CMV infection

Of these behaviors, please indicate those you have heard that may help in the prevention of cytomegalovirus (CMV) infection.

\begin{tabular}{|c|c|c|c|}
\hline Answer & $\begin{array}{l}\text { In all } \\
\mathrm{N}(\%)\end{array}$ & $\begin{array}{l}\text { Women } \\
\mathrm{N}(\%)\end{array}$ & $\begin{array}{l}\text { Men } \\
\mathrm{N}(\%)\end{array}$ \\
\hline Wash hands after diaper changes & $8(3.6)$ & $4(4.0)$ & $4(3.2)$ \\
\hline Avoid kissing a child on or near the mouth & $6(2.7)$ & $3(3.0)$ & $3(2.4)$ \\
\hline Avoid using the same dishes as child & $5(2.2)$ & $2(2.0)$ & $3(2.4)$ \\
\hline $\begin{array}{l}\text { Washing hands after wiping saliva or child's } \\
\text { nose }\end{array}$ & $8(3.6)$ & $3(3.0)$ & $5(4.0)$ \\
\hline $\begin{array}{l}\text { Avoiding sharing food and drinking with } \\
\text { child }\end{array}$ & $5(2.2)$ & $1(1.0)$ & $4(3.2)$ \\
\hline Washing baby toys & $6(2.7)$ & $3(3.0)$ & $3(2.4)$ \\
\hline $\begin{array}{l}\text { Washing hands after touching the baby } \\
\text { pacifier or toothbrush }\end{array}$ & $6(2.7)$ & $3(3.0)$ & $3(2.4)$ \\
\hline $\begin{array}{l}\text { Compliance with hygiene procedures at the } \\
\text { workplace }\end{array}$ & $17(7.6)$ & $7(7.1)$ & $10(7.9)$ \\
\hline I do not know any & $205(91.1)$ & 89 (89.9) & $116(92.1)$ \\
\hline
\end{tabular}

$\mathrm{N}$-number of students 


\section{DISCUSSION}

In an era of growing threats related to emerging epidemics worldwide, or new, rapidly spreading viral infections, it is very important to disseminate knowledge about these infections (sources and routes of infection, possible preventive measures, etc.) among the general public. This especially concerns a viral infection in the mother which can affect the normal development of the foetus [3]. A great deal of scientific research is being conducted in the field of congenital infections; for example, since the announcement of the first results of studies confirming perinatal [10] or prenatal [11] transmission of the Zika virus, hundreds of articles concerning congenital malformations associated with ZIKV infection during foetal life, models of virus transmission from mother to foetus, and a 'microcephaly epidemic' (over 3,000 cases in 29 countries) as an important public health problem, were published [12]. The last decade has also provided important information on many other viral congenital infections. New data have emerged concerning better management of congenital cytomegalovirus infection, including solid epidemiological data, good evidence for the accuracy of diagnosis of maternal CMV infection (correct diagnostic procedure), and good evidence for the feasibility of predicting the outcome of foetal infection [5]. However, from the point of view of public health, it is important whether these significant scientific achievements have a decisive impact on reducing the incidence of viral congenital infections. Due to the often asymptomatic course of some viral infections, ineffectiveness or inability to apply treatment and in the case of many viruses lack of vaccines, an obstacle to reducing the number of viral infections is primarily a lack of public awareness of preventive measures that can be taken to prevent them [13].

By implementing a vaccination programme against the rubella virus, the effective protection of women of childbearing age has been successfully achieved, and thus the cases of congenital rubella syndrome and the number of miscarriages and premature births as a result of RBV infection during pregnancy, have been successfully reduced [14]. Unfortunately, in the case of other viral infections, which may cause congenital infections, such as CMV, HSV, parvovirus, no effective immunization strategy is available. The basis for protecting pregnant women against infection is appropriate hygienic measures, as well as women's knowledge about sources or ways of spreading infection [15].

Therefore, the purpose of the survey conducted among adolescents studying in fields not related to medical sciences was to assess their knowledge/awareness of the topic of congenital infections, especially congenital CMV infection. Survey questions, apart from demographic data, concerned disease units and infections (mainly CMV), which may have a negative impact on fetal/child development. Knowledge of the sources of infection and the main routes of spread of cytomegalovirus infection and hygienic measures that significantly help to prevent this infection were assessed. Attention was been paid to knowledge of the term 'congenital CMV infection', and the fact that the cytomegalovirus can be transmitted from the mother to the foetus and can affect its proper development.

The respondents were aged 20-29, starting adult life and gaining experience important from the point of view of their further development. The data obtained on the basis of the analysis of questionnaires clearly indicated the necessity to broaden the knowledge possessed by young people (future parents) in at least one of the important areas related to public health - knowledge of congenital infections.

In addition to HIV infection, which was known to over $60 \%$ of respondents, no viral infection, which may have a negative impact on the developing foetus, was known to more than $10 \%$ of the group of students. Other disease units not directly related to the infectious agent, such as Down's syndrome, foetal alcohol syndrome, or autism, were known to at least $70 \%$ of the students. Knowledge of these and similar diseases was also dominant in other surveys. In a study conducted by Tastad et al. among recently pregnant and never pregnant women [16] in the USA, concerning foetal alcohol syndrome, sudden infant death syndrome and Down's syndrome, $90.7 \%$, $91.2 \%, 91.2 \%$ of recently pregnant women and $87.0 \%, 85.4 \%$, $89.9 \%$ never pregnant women, respectively, were aware of the diseases. In studies by Price et al. [17], knowledge of Down's syndrome, sudden infant death syndrome, autism and foetal alcohol syndrome, was declared by 95\%, 95\%, 96\% and $83 \%$ of respondents, respectively. In both cited studies, CMV congenital infection was known to approximately $20 \%$ of the women. Similar results were obtained in an Internet survey performed by the Cannon team [18]. In a group of 4,184 people, knowledge of infectious agents (except HIV) associated with abnormal foetal development, such as rubella and cytomegalovirus or Toksoplasma gondii, did not exceed $20 \%$, while diseases such as autism or Down's syndrome were known to over $90 \%$ of respondents. Knowledge about some pathogens and their relationship to congenital infections is greater in particular groups of society such as pregnant women or those planning pregnancy [19]. In a survey conducted by Lehman et al. [20], among 100 women who were pregnant or shortly after delivery, $55.7 \%$ of respondents had heard about toxoplasmosis, although most of them were unable to provide ways to prevent infection.

A significant impact on the knowledge of the problem is living in regions directly related to a given infection. Among 526 women of childbearing age (18-49 years) living in the northeastern part of Brazil, as many as $98.6 \%$ knew that Zika virus causes congenital infections, but only half of them $(50.2 \%)$ knew that the infection could be sexually transmitted [21]. In the majority of surveys conducted, awareness of CMV congenital infection was very low, and CMV infection was placed at the end of the listed, known diseases [16, 17, 18].

According to the data obtained in the presented study, the question 'Have you ever heard the term congenital cytomegalovirus (CMV) infection?' - 201 people (89.3\%) answered 'No'. In addition, $91.1 \%$ of students did not know that CMV infection could be dangerous to the foetus. Similar results were obtained in the case of knowledge about the sources of infection and the routes of spreading CMV infection. Almost $90 \%$ of students were unable to identify any clinical material that could be a source of a virus or activity associated with the risk of CMV infection. For comparison, in a study conducted among 10,190 students (69.2\%) and academic and administrative staff (30.8\%) at the University of Milan [22], more than a half of the respondents (52.5\%) had heard about cytomegalovirus, and $31.8 \%$ of them knew that it could cause congenital infection. In this group, only $16 \%$ of the respondents were unable to indicate any routes of virus transmission, and the remaining group of persons 
indicated saliva $(67.9 \%)$, blood $(67.6 \%)$, sexual contacts (58.4\%), transfusion/transplant (53.0\%), urine (42.7\%) and breast milk (42.2\%) as sources of infection. Those who were aware of the CMV congenital infection as hygiene measures that help prevent infection, indicated primarily not sharing a toothbrush and other bathroom utensils (75\%), not sharing the same cutlery with children (57\%), avoiding the saliva of other people (71.7\%), and washing hands after changing baby diapers (55.6\%). Unfortunately, there were also incorrect answers: cleaning the cat cuvette in gloves (35.4\%), not having contact with animals. In this study, as many as $91.1 \%$ of students could not indicate any hygiene measures.

\section{CONCLUSIONS}

1. Awareness of the problem of congenital infections among non-medical students who are potential parents in the future, is not satisfactory.

2. Simple hygiene measures allows significant reduction in the risk of infection with many viruses, including the cytomegalovirus, which is the most common cause of congenital infections worldwide, but awareness of this fact is very low among students.

3. Considering the fact that the surveyed group included women of childbearing age and who will become mothers in the near or distant future, low awareness of congenital CMV infection raises anxiety and, at the same time, indicates the need to undertake educational activities. Such activities should be aimed at informing future parents and the general public about the risk of infection, and the spread of viral infections that may cause congenital infections which can affect the foetus, and available methods for diagnosing maternal infection and possible preventive measures.

\section{REFERENCES}

1.Polonio CM, de Freitas CL, Zanluqui NG, Peron JPS. Zika virus congenital syndrome: experimental models and clinical aspects. J Venom Anim Toxins Incl Trop Dis. 2017; 23: 41. https:/doi:10.1186/ s40409-017-0131-x.

2. Frenkel LD, Gomez F, Sabahi F. The pathogenesis of microcephaly resulting from congenital infections: why is my baby's head so small? Eur J Clin Microbiol Infect Dis. 2018; 37(2): 209-226. https://doi:10.1007/ s10096-017-3111-8.

3. Silasi M, Cardenas I, Kwon JY, Racicot K, Aldo P, Mor G. Viral infections during pregnancy. Am J Reprod Immunol. 2015; 73(3): 199-213. https:// doi:10.1111/aji.12355

4. Arora N, Sadovsky Y, Dermody TS, Coyne CB. Microbial Vertical Transmission during Human Pregnancy. Cell Host Microbe. 2017; 21(5): 561-567. https://doi:10.1016/j.chom.2017.04.007

5. Leruez-Ville M, Ville Y. Fetal cytomegalovirus infection. Best Pract Res Clin Obstet Gynaecol. 2017; 38: 97-107. https://doi:10.1016/j. bpobgyn.2016.10.005
6. Naing ZW, Scott GM, Shand A, Hamilton ST, van Zuylen WJ, Basha J, et al. Congenital cytomegalovirus infection in pregnancy: a review of prevalence, clinical features, diagnosis and prevention. Aust N Z J Obstet Gynaecol. 2016; 56(1): 9-18. https://doi:10.1111/ajo.12408

7. Palma S, Roversi MF, Bettini M, Mazzoni S, Pietrosemoli P, Lucaccioni $\mathrm{L}$, et al. Hearing loss in children with congenital cytomegalovirus infection: an 11-year retrospective study based on laboratory database of a tertiary paediatric hospital. Acta Otorhinolaryngol Ital. 2019; 39(1): 40-45. https://doi: 10.14639/0392-100X-2020

8. Congenital CMV and Hearing Loss. https://www.cdc.gov/cmv/hearingloss.html (dostęp: 13.09.2019).

9. Counting the cost of CMV. The economic impact of CMV. https://www. cmvaction.org.uk (dostęp: 13.09.2019).

10. Besnard M, Lastere S, Teissier A, Cao-Lormeau V, Musso D. Evidence of perinatal transmission of Zika virus, French Polynesia, December 2013 and February 2014. Euro Surveill. 2014; 19(13): 20751.

11. Martines RB, Bhatnagar J, de Oliveira Ramos AM, Davi HP, Iglezias SD, Kanamura CT, et al. Pathology of congenital Zika syndrome in Brazil: a case series. Lancet 2016; 388(10047): 898-904. https://doi:10.1016/ S0140-6736(16)30883-2.

12. Epelboin S, Dulioust E, Epelboin L, Benachi A, Merlet F, Patrat C. Zika virus and reproduction: facts, questions and current management. Hum Reprod Update 2017; 23(6): 629-645. https://doi:10.1093/humupd/ dmx024

13. Lombardi G, Garofoli F, Stronati M. Congenital cytomegalovirus infection: treatment, sequelae and follow-up. J Matern Fetal Neonatal Med. 2010; Suppl 3: 45-48. https://doi:10.3109/14767058.2010.506753.

14. Bukasa A, Campbell H, Brown K, Bedford H, Ramsay M, Amirthalingam $\mathrm{G}$, et al. Rubella infection in pregnancy and congenital rubella in United Kingdom, 2003 to 2016. Euro Surveill. 2018; 23(19): 17-00381. https:// doi:10.2807/1560-7917.ES.2018.23.19.17-00381

15. Rawlinson WD, Boppana SB, Fowler KB, Kimberlin DW, Lazzarotto T, Alain S, et al. Congenital cytomegalovirus infection in pregnancy and the neonate: consensus recommendations for prevention, diagnosis, and therapy. Lancet Infect Dis. 2017; 17(6): e177-188. https://doi:10.1016/ S1473-3099(17)30143-3

16. Tastad KJ, Schleiss MR, Lammert SM, Basta NE. Awareness of congenital cytomegalovirus and acceptance of maternal and newborn screening. PLoS One. 2019; 14(8): e0221725. https://doi: 10.1371/journal. pone. 0221725

17. Price SM, Bonilla E, Zador P, Levis DM, Kilgo CL, Cannon MJ. Educating women about congenital cytomegalovirus: assessment of health education materials through a web-based survey. BMC Womens Health 2014; 14: 144. https://doi:10.1186/s12905-014-0144-3

18. Cannon MJ, Westbrook K, Levis D, Schleiss MR, Thackeray R, Pass RF. Awareness of and behaviors related to child-to-mother transmission of cytomegalovirus. Prev Med. 2012; 54(5): 351-357. https://doi:10.1016/j. ypmed.2012.03.009

19. Trzcińska A, Częścik A, Siennicka J. Stan wiedzy na temat zakażenia wrodzonego CMV wśród kobiet ciężarnych i planujących ciążę. Med Og Nauk Zdr. 2017; 23(3): 179-184. https://doi:10.26444/monz/76248

20. Lehmann LM, Santos PC, Scaini CJ. Evaluation of Pregnant and Postpartum Women's Knowledge about Toxoplasmosis in Rio Grande - RS, Brazil. Rev Bras Ginecol Obstet. 2016; 38(11): 538-544. https:// doi:10.1055/s-0036-1593970

21. Borges ALV, Moreau C, Burke A, Dos Santos OA, Chofakian CB. Women's reproductive health knowledge, attitudes and practices in relation to the Zika virus outbreak in northeast Brazil. PLoS One 2018; 13(1): e0190024. https://doi:10.1371/journal.pone.0190024

22. Binda S, Pellegrinelli L, Terraneo M, Caserini A, Primache V, Bubba L, et al. What people know about congenital CMV: an analysis of a large heterogeneous population through a web-based survey. BMC Infect Dis. 2016; 16(1): 513. https://doi: 10.1186/s12879-016-1861-z 